\title{
Antynomie i problemy polskiej demokracji A.D. 2019
}

\section{Antinomies and Problems of Polish Democracy 2019 AD}

\author{
Krzysztof Łabędź*
}

\begin{abstract}
Abstrakt
W tekście, na podstawie opracowań m.in. Giovanniego Sartoriego, Larry'ego Diamonda, Philippe'a Schmittera i Juana J. Linza, zawierających przedstawienie kluczowych potencjalnych wewnętrznych sprzeczności i paradoksów systemów demokratycznych, zostanie podjęta próba odpowiedzi na pytanie, jakie zasadnicze antynomie i problemy można wskazać w aktualnym funkcjonowaniu polskiego systemu politycznego. W odpowiedzi uwaga zostanie zwrócona m.in. na możliwości istnienia autonomicznej opinii publicznej, przyzwolenie dla realizacji modelu demoautorytarnego oraz sprzyjające temu cechy kultury politycznej, zakres oligarchizacji władzy, głębokość podziałów i konfliktów politycznych, a także zakres autonomii rządzących i państwa wobec Kościoła (jako instytucji względnie niezależnej od opinii publicznej).
\end{abstract}

Słowa kluczowe: demokracja w Polsce, opinia publiczna, kultura polityczna, konflikty polityczne, model demoautotytarny

\begin{abstract}
This article brings an attempt to answer the question of what fundamental antinomies and problems can be identified in the current functioning of the Polish political system. Krzysztof Łabędź has based his discussion on studies by, among other scholars, Giovanni Sartori, Larry Diamond, Philippe Schmitter, and Juan J. Linz, who identify the basic possible internal contradictions and paradoxes of democratic systems. In response to the above question, Łabędź draws attention, among other things, to the possibility of the existence of autonomous public opinion, to the consent to the implementation of the demo-authoritarian model and to the features of political culture that are conducive to it: the scope of the oligarchization of power, the depth of political divisions and conflicts, and the scope of the autonomy of the rulers and the state's independence from the Church (as an institution relatively independent of public opinion).
\end{abstract}

Keywords: democracy in Poland, public opinion, political culture, political conflicts, demoauthoritarian model

* Instytut Nauk o Polityce i Administracji, Akademia Ignatianum w Krakowie (krzysztof.labedz@ignatianum.edu.pl); iD https://orcid.org/0000-0003-2255-3338). 


\section{Wprowadzenie}

Powszechna jest opinia, że systemy demokratyczne pełne są wewnętrznych sprzeczności, paradoksów czy antynomii. Ich taksonomia prowadzi autorów do zróżnicowanych wniosków odnoszących się do możliwości względnie demokratycznego funkcjonowania systemów demokratycznych. W większości panowało i nadal na ogół panuje przekonanie, że wszelkie występujące trudności nie uniemożliwiają istnienia systemów demokratycznych. Niekiedy, jak w przypadku koncepcji Josepha Schumpetera, wymogi wobec systemu demokratycznego były ograniczane i sprowadzane do istnienia możliwości wyboru i reelekcji elity rządzącej, niekiedy formułowanym warunkiem było znalezienie „złotego środka”, niekiedy postulowano dokonanie odpowiednich reform.

W dalszej części opracowania zostanie przytoczonych kilka koncepcji wskazujących na sprzeczności, paradoksy i wewnętrzne zagrożenia demokracji (wydaje się, że wszystkie odnoszą się do demokracji liberalnej). Na ich podstawie zostanie podjęta próba odpowiedzi na pytanie o to, które z nich występują aktualnie w Polsce oraz jakie można wskazać ich uwarunkowania. Formułowane opinie będą miały przede wszystkim charakter pytań i hipotez, a ponadto trzeba pamiętać, że konieczne uogólnienia nie dotyczą wszystkich polityków czy całości społeczeństwa. Mówiąc o demokracji, mam na myśli istniejący w Polsce system, który do niedawna był zbliżony do modelu demokracji liberalnej ${ }^{1}$, a obecnie coraz bardziej oddala się od tego modelu. Trzeba też dodać, że wiele zbliżonych problemów występuje także w innych krajach. Tekst powstał przede wszystkim na podstawie analizy dokumentów, aktów prawnych, wyników badań, wypowiedzi polityków.

\section{Wybrane koncepcje wskazujące problemy związane z demokracją}

Giovanni Sartori w Teorii demokracji wskazuje na trzy zasadnicze możliwe zagrożenia nieodłącznie wiążące się z systemami demokratycznymi: brak racjo-

${ }^{1}$ Nie wdając się w głębsze rozważania definicyjne, demokrację liberalną (tzn. taką, w której większość uzyskana w wyniku wyborów jest w swoich działaniach ograniczona) na użytek niniejszego tekstu można scharakteryzować przez podanie m.in. następujących cech: istnieją wszystkie instytucjonalne gwarancje poliarchii wymienione przez Roberta Dahla (zob. m.in. Dahl, Stinebrickner, 2007, s. 127-129), rządzący w trakcie kadencji podlegają kontroli ze strony wyspecjalizowanych instytucji (dotyczy to m.in. zgodności stanowionego prawa z konstytucją oraz przestrzegania innych zasad państwa prawa), istnieją silne gwarancje praw obywatelskich, w tym praw mniejszości, które są przez rządzących przestrzegane. 
nalności po stronie wyborców (opinii publicznej), sprawowanie rządów zawsze przez niewielką grupę (elitę władzy), traktowanie większości wyborczej jako uprawniającej do rządów większości (tyranii większości, m.in. łamiącej prawa opozycji). Choć autor udowadnia, że w demokracji konieczne jest jedynie istnienie autonomicznej opinii publicznej (a racjonalność musi być cechą wybranych przedstawicieli), że rządząca elita musi liczyć się z wyborcami (zwrotna teoria demokracji), a w rzeczywistości nie ma żadnej trwałej większości społecznej, warto pamiętać o wskazanych niebezpieczeństwach (Sartori, 1998, rozdz. 5 i 6$)$.

Philippe Schmitter problemy i zagrożenia demokracji dzieli na należące do istoty demokracji i zewnętrzne wobec niej - tu zostaną wymienione jedynie te pierwsze. Należą do nich: oligarchia (uzyskanie trwałej przewagi przez przywódców), ,jazda na gapę", czyli brak aktywności obywateli, ,cykle polityczne" - niestabilność koalicji i większości podejmujących decyzje, funkcjonalna autonomia, czyli istnienie instytucji, które muszą zachować niezależność od nacisków opinii publicznej i rywalizacji partyjnej, oraz współzależność w ramach sieci powiązań międzynarodowych (Schmitter, 2005, s. 20-22).

Trzy paradoksy demokracji wymienił Larry Diamond. Pierwszy z nich to napięcie pomiędzy dwoma koniecznymi zjawiskami - konfliktem i konsensem: „[...] demokracja potrzebuje konfliktów, ale nie nadmiernych; musi występować rywalizacja, ale jedynie w ściśle określonych i powszechnie akceptowanych ramach. Podziały muszą być łagodzone przez konsensus" (Diamond, 2005, s. 40). Drugi to sprzeczność pomiędzy reprezentatywnością a sterownością - z jednej strony władze muszą reagować na roszczenia różnych grup interesów i poddawać się społecznej kontroli, z drugiej - zachować autonomię pozwalającą na podejmowanie decyzji politycznych i ich implementację w sposób szybki i energiczny. Trzeci paradoks dotyczy sprzeczności pomiędzy przyzwoleniem a efektywnością. Demokracja opiera się na przyzwoleniu rządzonych (legitymizacji), co wymaga skutecznego, efektywnego działania (szczególnie w sferze ekonomicznej), które może prowadzić do wycofania tego przyzwolenia (Diamond, 2005, s. 40-54).

W nieco inny sposób problemy demokracji ukazuje Mirosław Karwat, który stosując wiele kryteriów, rozróżnia kilka wzorców pseudodemokratycznych, mogących ukrywać się pod demokratycznymi normami prawnoustrojowymi oraz demokratyczną frazeologią. Problemem jest zatem rozbieżność pomiędzy przyjętymi i głoszonymi założeniami ustrojowymi a rzeczywistym stanem i jakością demokracji. Autor wymienia następujące wzorce: anarchistyczny, demoliberalny, paternalistyczny model „demokracji kierowanej”, demokracji fasadowej oraz wzorzec demoautorytarny (Karwat, 2016). Wydaje się, że dla charakterystyki wspomnianej rozbieżności w Polsce szczególnie interesujący jest ten ostatni, obejmujący autorytarny styl rządzenia z zachowaniem pozorów demokratyzmu. 
Juan J. Linz pisząc o mechanizmie upadku demokracji, szczególną wagę przywiązywał do działań opozycji, której nielojalne zachowanie wobec istniejącego systemu było jedną z istotnych przyczyn tego procesu (Linz, 1998, s. 40-46). W sytuacji panującej Polsce przed 2015 rokiem opozycja również przyczyniała się do delegitymizacji istniejącego ówcześnie systemu², a można to uznać za budowanie podstaw zachodzących później zmian. Już jako siła rządząca zaczęła je wprowadzać i okazało się, jak kluczowa dla trwania systemu demokratycznego jest podkreślana przez Linza jakość klasy politycznej, przywiązanie przywódców do demokracji, jej inkluzyjnego charakteru, szacunek dla konstytucji czy styl dyskursu politycznego (Linz, 1998, s. 390-394). Podobnie o zależności realnego kształtu i jakości demokracji od jakości klasy (elity) politycznej piszą inni badacze - m.in. jest to jedno z zasadniczych twierdzeń neofunkcjonalnego paradygmatu elitystycznego Johna Higleya i współpracowników (Żyromski, 2007, rozdz. 10), a Joseph Schumpeter wśród warunków powodzenia systemu demokratycznego na pierwszym miejscu wymienił konieczność odpowiedniego poziomu jakościowego polityków (Schumpeter, 2009, s. 362). Można tutaj także przytoczyć słowa Jerzego Wiatra stwierdzającego, że wiele instytucji demokracji przedstawicielskiej ,zbudowano, opierając się na założeniu, że wszyscy kierować się będą dobrą wolą i działać będą nie tylko zgodnie z literą, ale także zgodnie z duchem, demokratycznego państwa prawa" (Wiatr, 2019, s. 123).

Kończąc te wstępne uwagi, trzeba dodać, że jako usprawiedliwienie dla odchodzenia od zasad demokracji liberalnej trudno uznać stwierdzenie, że demokracja dalej istnieje, ale jako nieliberalna. Wypowiedział się na ten temat m.in. Andrzej Zoll, stwierdzając, że demokracja jest albo liberalna, albo jej nie ma (Werdykt..., 2018), a przekonująco uzasadnił Andrzej Antoszewski. Udowodnił on, że demokracja nieliberalna nie jest realizacją modelu większościowego (scharakteryzowanego przez Arendta Lijpharta), ale jest formą tyranii większości (Antoszewski, 2019, s. 108-111).

Nie wszystkie wymienione $\mathrm{w}$ dalszej części opracowania problemy znajdą zastosowanie do analizy aktualnej sytuacji w Polsce. Wydaje się, że najbardziej przydatne będą następujące kwestie: możliwości istnienia autonomicznej opinii publicznej, realizacja modelu demoautorytarnego oraz sprzyjające temu cechy kultury politycznej (przyzwolenie), zakres oligarchizacji władzy, głębokość podziałów i konfliktów politycznych oraz zakres autonomii rządzących i państwa wobec Kościoła (jako instytucji względnie niezależnej od opinii publicznej).

2 Świadczą o tym np. następujące odpowiedzi w badaniach przeprowadzonych w 2011 roku: nasze społeczeństwo urządzone jest sprawiedliwie - tak 20,6\%, nie $72,6 \%$; organizacja społeczeństwa wymaga radykalnej zmiany - tak 72\%, nie 20\% (Skarżyńska, 2012, s. 537-538) . 


\section{Wybrane problemy związane z demokracją w Polsce}

1. Zacząć można od problemu dotyczącego wszystkich systemów demokratycznych, związanego m.in. z podkreślaną przez Sartoriego koniecznością istnienia autonomicznej opinii publicznej oraz dostępu do wielu źródeł informacji, będącego zdaniem Roberta Dahla jedną z instytucjonalnych gwarancji demokracji. W aktualnych uwarunkowaniach powstają bowiem pytania: Czy realnie może istnieć autonomiczna opinia publiczna? Czy pluralizm źródeł informacji nie jest pewnym złudzeniem? Według raportu Oxford Internet Institute dotyczącego wykorzystania Internetu w kampanii wyborczej do Sejmu w 2015 roku bardzo niewielka liczba kont internetowych odpowiadała za nieproporcjonalnie dużą część aktywności w dyskusjach politycznych dotyczących określonych hasztagów. Stwierdzono, że około 1/3 tej aktywności można przypisać botom (więcej niż we Francji, Niemczech czy Wielkiej Brytanii). Jako trzy zasadnicze elementy informatycznej propagandy wymieniono: polityczne boty udające prawdziwych użytkowników, zorganizowany trolling (w tym kampanie nienawiści i prześladowań) oraz rozpowszechnianie „fake newsów” (Raport..., 2017). Internetowa propaganda jest obecna przede wszystkim na portalach społecznościowych (w Polsce użytkowników Facebooka jest ok. 22,6 mln), a warto przy tym pamiętać, że stosuje się też automatyczne wzmacnianie określonych treści (np. przez „polubienia”, udostępnianie, hasztagi czy rozsyłanie wiadomości ${ }^{3}$ ), a treści najczęstsze trafiają na czołowe miejsca w przeglądarkach (blisko 90\% użytkowników nie wychodzi poza pierwszą ukazującą się w przeglądarce stronę). Nie bez znaczenia są również pewne prawidłowości o charakterze psychologicznym, a mianowicie silne w Polsce tendencje do pozostawania w bańce informacyjnej oraz poszukiwanie potwierdzenia własnych poglądów, uniemożliwiające korzystanie ze zróżnicowanych źródeł informacji. W dodatku, prawidłowością kształtowania się świadomości społecznej jest uzależnienie indywidualnych poglądów od tego, co sądzą inni, dogmatyzacja, w której wyniku prawdziwe staje się nie to, co jest zgodne z rzeczywistością, ale to, co myślą inni. Powstają zatem pytania: Czy opinia publiczna podlegająca silnej manipulacji i dezinformacji medialnej może być autonomiczna? Czy możemy mówić o rzeczywistym pluralizmie źródeł informacji? Nie są to problemy nowe, ale w dobie rozwoju Internetu zyskujące na znaczeniu?

2. Do zasadniczych antynomii polskiej demokracji należy przede wszystkim $\mathrm{z}$ jednej strony, istnienie procedur wybierania rządzących, a z drugiej - możli-

${ }^{3}$ Podobno w trakcie protestu przeciwko reformie sądownictwa wysyłano 300 tweetów na minutę mówiących, że protesty to skoordynowana i opłacona akcja marketingu politycznego (Nowak, 2017). 
wość ograniczenia czy wręcz likwidacji przez wybranych przedstawicieli demokratycznych zasad funkcjonowania systemu politycznego. Sytuację tego rodzaju opisał Karwat, określając ją jako model demoautorytarny: „Formalnie rządzi się z demokratyczną legitymacją wyborczą, w ramach demokratycznych reguł gry, eksponując swój demokratyzm głównie w sferze uznanych rytuałów i procedur, traktowanych jednak wybiórczo, instrumentalnie i fasadowo" (Karwat, 2016, s. 32). Dalszy opis tego wzorca można traktować jako dokładne odzwierciedlenie aktualnej sytuacji w Polsce - uzyskanie większości wyborczej (oraz w sondażach) traktowane jest jako upoważnienie do wszystkich podejmowanych działań (w których odwołuje się do „woli suwerena”), w tym do praktycznego likwidowania lub ograniczania istniejących mechanizmów kontroli, dążenia do realizacji zasady jednolitości władzy państwowej, centralizacji władzy i arbitralnego sposobu podejmowania decyzji (Karwat, 2016, s. 32-34). Warto przypomnieć, że jednym $\mathrm{z}$ warunków definicyjnych demokracji w ujęciu normatywnym jest zastrzeżenie, że lud nie może ograniczyć ani znieść mechanizmów demokratycznych.

Rodzi się więc pytanie: Czy wybór (już ponowny) sił ograniczających mechanizmy demokratyczne oraz pozytywne oceny dokonywanych zmian to przejaw demokracji (przede wszystkim w jej ujęciu substancjalnym/materialnym), realizacja zasady suwerenności ludu (narodu), czy też raczej jej zaprzeczenie (m.in. z punktu widzenia zasady podziału władzy, czy zasady państwa prawa, ale również w wymiarze aksjologicznym)?

3. Należy więc zastanowić się, co leży u podstaw dokonywanego ostatnio wyboru rządzących. W ten sposób dochodzimy do kolejnej z zasadniczych w moim przekonaniu antynomii - sprzeczności pomiędzy istniejącymi procedurami demokratycznymi a postawami i aspiracjami obywateli. Wiatr, stwierdzając, że „Trwałość nowych autorytaryzmów nie wynika ze stosowania przemocy, lecz z utrzymywania się poparcia politycznego" (Wiatr, 2019, s. 120), wymienił trzy społeczne źródła autorytaryzmu: frustrację warstw uboższych (nie tylko ze względów ekonomicznych, ale również społeczno-politycznych), źródła kulturowe (m.in. konserwatyzm, obawa przed modernizacją, nacjonalizm) oraz erozję instytucji demokratycznych w dotychczasowej postaci (Wiatr, 2019, s. 120-122). Bardziej szczegółowe omówienie tych źródeł w odniesieniu do Polski nie jest możliwe ze względu na ograniczoną objętość tekstu, dlatego szczególna uwaga zostanie poświęcona jedynie jednemu ze źródeł kulturowych - niektórym przeważającym $\mathrm{w}$ społeczeństwie postawom i poglądom odnoszącym się do demokracji.

Czynnikiem ułatwiającym odchodzenie od zasad demokracji jest stosunek społeczeństwa polskiego do demokracji, który jest co najmniej ambiwalentny. $\mathrm{Z}$ jednej strony termin demokracja kojarzy się pozytywnie, z drugiej - większość nie jest przekonana do wartości demokracji, a poglądy znacznej 
części społeczeństwa są niezgodne z demokratycznymi wartościami. W badaniach CBOS regularnie na pytanie: Czy demokracja ma przewagę nad innymi formami rządów? - ok. 70\% indagowanych udziela odpowiedzi twierdzącej, a na pytanie: Czy w pewnych okolicznościach rządy niedemokratyczne mogą być lepsze? - ponad połowa badanych twierdzi, że nie. Jeśli jednak wszystkie wskaźnikowe dla stosunku do demokracji odpowiedzi zbierze się razem, wynik jest zdecydowanie inny. Widać to wyraźnie na skali akceptacji demokracji, stosowanej w badaniach „Diagnoza społeczna”, wskazującej, iż uznanie demokracji nie jest poglądem dominującym. W 2015 roku, obok 29\% wybierających pogląd, że demokracja ma przewagę nad wszelkimi innymi formami rządów, $14 \%$ stwierdziło, że niekiedy rządy niedemokratyczne mogą być lepsze, 17,2\% - że nie ma znaczenia, czy rząd jest demokratyczny, czy niedemokratyczny, $4,7 \%$ - że demokracja jest złą formą rządów, a 35,2\% nie udzieliło odpowiedzi (Czapiński, 2015, s. 322). Nawet jeśli proporcje te uległy jakimś zmianom, to nie są one zasadnicze.

W dodatku wyniki badań wskazują, że choć demokracja kojarzona jest przede wszystkim z wolnymi wyborami ( $92 \%$ uważa to za ważne), równością wobec prawa $(88 \%)$ czy ochroną wolności osobistej $(86 \%)$, to nie mniej ważne są takie kwestie, jak zapewnienie dzieciom ze wszystkich rodzin równych szans kształcenia (87\%), finansowanie przez państwo ochrony zdrowia, nauki, kultury (83\%) czy też dbałość rządu o dobrobyt obywateli (80\%) (Zasady..., 2017). Zatem dla znacznej części społeczeństwa kwestie materialne są równie ważne, jak procedury demokratyczne, a na podstawie wyników niektórych innych badań można sądzić, że nawet ważniejsze. Znaczy to, że w sytuacji, kiedy rządy PiS są pozytywnie oceniane (świadczą o tym zarówno wyniki badań opinii publicznej, jak ostatnich wyborów), a większość wystawiających dobre oceny (51\%) jako zasadniczy argument wymienia zmiany zachodzące w sferze społecznej i gospodarczej (zob. Ocena rządów PiS..., 2019), można sądzić, że wprowadzane ograniczenia zasad demokratycznych dokonujące się z naruszaniem konstytucji (co zresztą przyznaje większość badanych) po pierwsze, jest rekompensowane zmianami w sferze socjalnej, a po drugie, przez część społeczeństwa może być traktowane jako realizacja ,prawdziwej” demokracji ${ }^{4}$.

Z przytoczonymi wynikami pozostają w zgodzie rezultaty badań autorytaryzmu świadczące o tym, że charakteryzuje on znaczną część społeczeństwa polskiego, choć obecnie jego poziom jest najniższy (podobnie jak w przypadku anomii i alienacji) od początku badań. Niemniej jednak w 2019 roku 51\% respondentów zgadzało się z poglądem, że ,silny przywódca może więcej zrobić dla kraju niż ustawy, dyskusje, konsultacje" (Psychologiczne..., 2019), a ponad

${ }^{4}$ Można tu zacytować zdanie opisujące poglądy podhalańskich górali: „Prawdziwa demokracja to przede wszystkim dobrobyt, ale nie tylko, to także sprawiedliwość [...]" (Malewska-Szałygin, red., 2005, s. 12). 
$40 \%$ badanych akceptowało klasyczny wskaźnik postawy autorytarnej, zgadzając się ze stwierdzeniem, że ,jak się dobrze zastanowić, to trzeba przyznać, że istnieją na świecie tylko dwa typy ludzi: silni i słabi” (Psychologiczne..., 2019).

Postawy autorytarne widoczne są również w innych kwestiach, m.in. w poglądach odnoszących się do mniejszości homoseksualnych - niemal $80 \%$ badanych uważa, że homoseksualizm to odstępstwo od normy, przy czym $24 \%$ twierdzi, że homoseksualizmu nie wolno tolerować. Zdecydowana większość opowiada się przeciwko możliwości zawierania związków małżeńskich przez osoby tej samej płci (66\%), adopcji dzieci przez pary homoseksualne $(84 \%)$, publicznemu pokazywaniu swojego stylu życia przez osoby homoseksualne (67\%) (Stosunek Polaków..., 2019). Do tego rodzaju postaw często odwołują się ostatnio czołowi politycy PiS.

W wyraźnej sprzeczności z zasadami demokracji pozostaje też sposób postrzegania społeczeństwa szeroko obecny w społeczeństwie polskim, stwierdzony z zastosowaniem skali dominacji społecznej - odmawianie niektórym ludziom i grupom prawa do szacunku, ich moralna dyskryminacja, czyli uznanie, że są gorsi. Postawę taką autorzy „Diagnozy społecznej 2015” przypisują niemal połowie społeczeństwa (46,5\%) (Czapiński, 2015, s. 317). Koresponduje to ze stosowaną często przez PiS retoryką zawierającą dychotomiczny obraz społeczeństwa, w którym podział ściśle wiąże się z wartościowaniem w kategoriach moralnych: my - dobrzy, oni - źli. Podział taki jest jednym z elementów negatywnego kapitału społecznego, zasobu przeciwdziałającego rozwojowi społeczeństwa obywatelskiego.

Chcąc krótko podsumować poglądy społeczeństwa związane z demokracją i jej realizacją w Polsce, można powiedzieć, że dla większości społeczeństwa istnienie demokracji i przestrzeganie zasad demokratycznych nie jest czymś bardzo ważnym, a poparcie dla demokracji ma przede wszystkim charakter werbalny (wartość uznawana). Ocena demokracji w Polsce wydaje się mocno uzależniona od postępów w zaspokajaniu potrzeb materialnych, a w mniejszym stopniu stanowi wynik oceny innych aspektów polityki partii rządzącej. Pytanie, które się tutaj nasuwa, brzmi następująco: Czy w społeczeństwie w większej części mającym wskazane uprzednio poglądy, możliwe jest funkcjonowanie demokracji liberalnej?

4. W związku $\mathrm{z}$ wyrażonym $\mathrm{w}$ wyborach poparciem społecznym dla rządzących, problem oligarchizacji władzy jest złożony, bo przecież rządzący poddali się demokratycznej kontroli ze strony elektoratu, a wyborcy docenili realizację wielu obietnic złożonych przed poprzednimi wyborami. Doceniono poprawę materialnego poziomu życia, zmniejszenie bezrobocia, duża część społeczeństwa ocenia, że system działa bardziej sprawiedliwie niż poprzednio. Jednak pewne wątpliwości może budzić poziom zainteresowania wyborców zagadnieniami politycznymi oraz poziom podmiotowości obywatelskiej (alienacji). 
Istnieje także druga strona tego zagadnienia, związana m.in. $\mathrm{z}$ charakterem i sposobem działania relewantnych partii politycznych oraz sposobem ustalania list wyborczych.

Zainteresowanie polityką $\mathrm{w}$ społeczeństwie polskim jest bardzo słabe: w 2019 roku, przed wyborami do Parlamentu Europejskiego, jako duże określiło je $3 \%$ badanych, jako średnie $-8 \%$, jako małe $-22 \%$, a jako żadne $-51 \%$ (Odbiór kampanii wyborczej..., 2019). Można to uznać za wskaźnik poziomu świadomości podczas oceniania i kontrolowania rządzących. Jeśli chodzi o poczucie wpływu na działanie rządu, to wzrosło ono - co prawda - w ostatnich latach, ale w dalszym ciągu prawie $2 / 3$ badanych deklaruje, że ludzie tacy, jak oni, nie mają żadnego wpływu na to, co robi rząd (Wybory samorzadowe..., 2018).

Na problem oligarchizacji można patrzeć także przez pryzmat sposobu działania partii politycznych. W najsilniejszych partiach politycznych znaczną rolę odgrywają ich przywódcy, którzy często kierują nimi w sposób autokratyczny. Na przykładzie prezesa PiS, mającego bardzo silną pozycję zarówno opartą na autorytecie, jak i wynikającą z zasad statutowych, można sądzić, że w partii praktycznie nie podlega on żadnej kontroli. Ostatecznie prezes, być może z udziałem wąskiej grupy kierowniczej, decyduje o sprawach programowych, określa strategię i taktykę, podejmuje wiążące decyzje personalne, dotyczące obsady stanowisk w instytucjach państwowych. Ścisłe kierownictwo partyjne decyduje o kształcie list wyborczych w wyborach parlamentarnych, szczególnie o obsadzie czołowych miejsc, a jak wskazują badania, kandydaci z tych miejsc stanowią ok. $80 \%$ wybranych przedstawicieli.

Pojawia się pytanie, na które odpowiedź jest praktycznie niemożliwa, o zakres myślenia grupowego w kierownictwie partii rządzącej. Występowanie syndromu myślenia grupowego, traktowanego jako jedna z patologii świadomości społecznej, obejmującego m.in. złudzenie nieograniczonej siły i bezkarności, niepodważalną wiarę w swoją wyższość moralną, silne akcentowanie lojalności wobec własnej grupy jako największej cnoty, traktowanie odmienności poglądów w kategoriach moralnych, autocenzurę, tworzenie złudzenia jednomyślności (zob. Sztompka, 2002, s. 304-306), znajduje potwierdzenie choćby w jednolitości wypowiedzi dla mediów (tzw. przekaz dnia), lekceważącym stosunku do osób mających inne poglądy (przykładem traktowanie opozycji w parlamencie), a nawet odmawianiu im moralnego prawa do uczestniczenia $\mathrm{w}$ życiu publicznym („łże elity”, „gorszy sort”, „mordy zdradzieckie” itp.). Jednym ze skutków występowania takiego syndromu jest na pewno pogłębianie się rzeczywistej oligarchizacji władzy.

Choć listy wyborcze konstruowane są z uwzględnieniem popularności kandydatów wśród wyborców, a partia rządząca poddała się ocenie wyborców, powstaje pytanie: Jaki jest zakres oligarchizacji władzy, realny wpływ wyborców na realizowaną politykę, skład parlamentu, a pośrednio także na to, kto będzie sprawował władzę wykonawczą? 
5. Dość powszechnie przyjmowane jest twierdzenie, że w ostatnich latach nasilił się konflikt i podział polityczny, zarówno w ramach klasy politycznej, jak i w całym społeczeństwie. Konflikt coraz wyraźniej ma charakter dychotomiczny, jego strony można określać jako PiS i anty-PiS, a ponadto można się zastanawiać, czy nie postępuje stała polaryzacja jego stron. Ponadto wydaje się, że konfliktowa koncepcja uprawiania polityki powoduje stopniowe ,przyzwyczajenie" obserwatorów do tego, że dzielenie społeczeństwa i konflikt są czymś normalnym. Jednym $\mathrm{z}$ efektów może być coraz częściej obecna w przestrzeni publicznej mowa nienawiści.

Na podstawie wyników badań przeprowadzonych w roku 2014 i powtórzonych dwa lata później stwierdzono, że liczba młodych Polaków, spotykających się z antysemicką, antymuzułmańską czy antyukraińską mową nienawiści wzrosła od ok. połowy do ok. 3/4. Badacze doszli do wniosku, że konsekwencją tego jest przyzwyczajenie się do tej patologii: „,...] im większy jest kontakt z mową nienawiści $\mathrm{w}$ otoczeniu, tym bardziej ludzie się z nią oswajają, przestając postrzegać mowę nienawiści jako poważny problem społeczny" (Winiewski i in., 2017). Z początkiem 2019 roku badania wykazały, że ponad 80\% respondentów spotkało się z przejawami takiej mowy osobiście, najczęściej w Internecie oraz $\mathrm{w}$ telewizji. Charakterystyczne jest przy tym to, że dostrzeganie mowy nienawiści zależy od orientacji politycznej - częściej dostrzegają ją i uważają za poważny problem osoby o poglądach lewicowych i centrowych (93\%) niż deklarujące poglądy „zdecydowanie prawicowe” (73\%) (Mowa nienawiści..., 2019).

Wskaźnikiem pogłębiania się podziałów politycznych w społeczeństwie mogą być również oceny tego zjawiska formułowane przez respondentów w trakcie badań opinii publicznej. W 2017 roku zadano badanym pytanie o to, czy społeczeństwo dziś jest mniej czy bardziej podzielone i skonfliktowane niż przed wyborami w 2015 roku i uzyskano m.in. następujące odpowiedzi: 47\% - bardziej podzielone, skonfliktowane, $27 \%$ - tak samo, a jedynie $2 \%$ wybrało odpowiedź, że w ogóle nie jest podzielone ani skonfliktowane. Jako najbardziej dzielące $65 \%$ wskazało przy tym kwestie związane z polityką $(O$ polityce..., 2017). W badaniach z września 2019 roku już 84\% respondentów stwierdziło, że w ostatnich latach podziały między Polakami zrobiły się głębsze niż kiedyś, $31 \%$ obwiniało o to PiS, 26\% - opozycję, a 41\% - jednych i drugich (Polacy coraz bardziej podzieleni..., 2019).

Ciekawe wyniki przyniosło badanie przeprowadzone pod koniec 2018 roku, a zasadniczym wnioskiem było stwierdzenie, że zwolennicy i PiS, i partii opozycyjnych mają negatywny stosunek do swoich oponentów politycznych, co można traktować jako wskaźnik polaryzacji politycznej (Płociński, 2019).

Problem występowania silnego konfliktu w sferze politycznej można zobrazować, charakteryzując sytuację opozycji parlamentarnej w kadencji parlamen- 
tu zakończonej w 2019 roku. Nie znaczy to, że sytuacja opozycji w poprzednich kadencjach była zasadniczo odmienna, lecz nigdy wcześniej ograniczenia dla opozycji nie były tak silne i realizowane w takim stylu. Warto tu wskazać na najczęściej występujące sposoby ograniczania możliwości działania opozycji parlamentarnej, do których należą:

- brak reakcji na wnioski o przedstawienie opinii i ekspertyz, w tym dotyczących zgodności projektów ustaw z konstytucją, opinii ministerstwa, oceny skutków, a także nieuwzględnianie opinii negatywnych;

- ograniczanie czasu wypowiedzi parlamentarnych (nawet do pół minuty), odbieranie głosu, wyłączanie mikrofonu, zamykanie dyskusji mimo zgłoszeń do zabrania głosu;

- nieprzestrzeganie terminów regulaminowych - 7 dni od złożenia projektu do jego procedowania czy zawiadamiania o posiedzeniu komisji 3 dni wcześniej; dostarczanie dokumentów w ostatniej chwili - w tych kwestiach najczęściej przegłosowywano skrócenie terminów;

- blokowanie poprawek i wniosków - łączne głosowanie bardzo wielu poprawek zblokowanych nie merytorycznie, ale ze względu na autora (co było kwestionowane przez legislatorów);

- brak reakcji na zgłaszane opinie różnego rodzaju organizacji o wątpliwościach konstytucyjnych, niedopuszczanie do głosu ich przedstawicieli;

- wprowadzenie zmian w ustawie o wykonywaniu mandatu posła i senatora, a następnie zmian $w$ regulaminie sejmu dostosowujących jego zapisy do tejże ustawy, z których zasadnicza dotyczy możliwości karania parlamentarzystów za zachowania naruszające powagę instytucji parlamentarnych przez obniżenie uposażenia (nawet o połowę przez 3 miesiące) i diet czy ograniczenia możliwości wyjazdów zagranicznych - jak się okazało, regulacje te służyły niemal wyłącznie karaniu posłów opozycji, których ukarano ok. dwudziestu.

Pytanie, jakie nasuwa się po przedstawieniu przejawów konfliktów i podziałów, dotyczy możliwości współpracy w sferze politycznej, uzyskania konsensu w ważnych sprawach, nie mówiąc już o wdrażaniu procedur deliberacyjnych. W związku z rozszerzającą się patologią życia publicznego, jaką jest mowa nienawiści, rodzi się także pytanie o to, gdzie przebiega granica pomiędzy wolnością słowa a jej nadużywaniem. Można dodać, że próba ograniczenia mowy nienawiści podjęta na forum parlamentarnym została przez PiS odrzucona właśnie $\mathrm{z}$ uzasadnieniem, że byłoby to ograniczenie wolności słowa.

6. Ostatni z poruszanych tu problemów dotyczy kwestii związanych z neutralnością światopoglądową państwa. Problemem jest z jednej strony zaangażowanie Kościoła instytucjonalnego w toczące się spory polityczne, z drugiej - starania wielu polityków o poparcie ze strony Kościoła i wykorzystywanie przez nich religii i Kościoła do uzyskania takiego poparcia. Cała historia III RP wskazuje, 
że opinia i stanowisko Kościoła, a właściwie jego hierarchii, była zawsze brana pod uwagę przez rządzących ${ }^{5}$, ale dopiero w okresie samodzielnego sprawowania władzy przez PiS Kościół uzyskał tak znaczny wpływ na politykę władz. Jest to zaprzeczenie założeniom normatywnym obecnym zarówno w dokumentach Kościoła, jak i w przepisach prawa polskiego. Mówiąc bardzo ogólnie, Kościół instytucjonalny w większości popiera PiS jako partię najsilniej deklarującą przywiązanie do religii i Kościoła, i najpełniej gwarantującą uprzywilejowanie Kościoła oraz duchownych w państwie. Politykę uwzględniającą zasady moralne Kościoła (choć nie we wszystkim) zadeklarował prezes PiS, stwierdzając, że alternatywy dla wartości reprezentowanych przez naukę moralną Kościoła jest jedynie nihilizm (wypowiedź ta wyraźnie wyklucza wszystkich przyjmujących inne wartości i jest niezgodna m.in. z zapisem obecnym w preambule Konstytucji) (Jarosław Kaczyński: Poza Kościołem..., 2019). Z kolei PiS potrzebuje Kościoła jako instytucji mającej zdolność mobilizacji pewnej części elektoratu, ale także do legitymizowania zmian wprowadzanych często z naruszaniem Konstytucji.

Przykładem wykorzystywania religii i Kościoła do celów politycznych może być fakt, że w uroczystościach religijnych biorą udział politycy, wygłaszając często przemówienia niemające wiele wspólnego z religią. Liczni przedstawiciele władz, w tym premier i ministrowie, wzięli udział w uroczystościach kończących 27. pielgrzymkę Rodziny Radia Maryja na Jasną Górę. Mateusz Morawiecki dokonał zawierzenia kraju Matce Bożej i poddał krytyce przeciwników rządu. Działo się to w obecności ponad stu tysięcy osób, a zatem wystąpienia polityków można potraktować nie tylko jako hołd dla o. Tadeusza Rydzyka, ale także jako starania o poparcie zgromadzonego pod Jasną Górą elektoratu (Pielgrzymka..., 2018).

Poparcie dla PiS podtrzymuje w swoich mediach o. Rydzyk oraz biskupi wspierający Radio Maryja. Podczas obchodów 24. urodzin Radia Maryja w Toruniu Jarosław Kaczyński dziękował o. Rydzykowi za to, co zrobił dla polskiego Kościoła i dla Polski, oraz podkreślił, że „nie byłoby zwycięstwa bez Rodziny Radia Maryja" (Kaczyński: nie byłoby zwycięstwa..., 2015).

Powstaje zatem kolejne pytanie: Czy możliwa do pogodzenia z demokracją jest silna pozycja polityczna i uprzywilejowanie jednego z Kościołów (instytu-

${ }^{5}$ Można przytoczyć słowa Agaty Chełstowskiej, jednej z autorek raportu z badań relacji państwowo-kościelnych w III RP (z 2013 roku), przeprowadzonych przez Instytut Spraw Publicznych: „Biskupi mają większy wpływ na legislację niż przewiduje to konstytucja. Nie mówi się o lobbingu Episkopatu na rząd, tylko o „spotkaniach w ramach Komisji Wspólnej”. Politycy są bardzo czuli na każde słowo biskupów, które pojawia się w mediach. Bardziej przejmują się ich głosem niż głosem swoich wyborców, co widać na przykładzie Konwencji o zwalczaniu przemocy. Tu chodzi o zdrowy rozsądek, o ochronę kobiet przed przemocą i konkretne rozwiązania, które to umożliwią. Państwo i tak powinno te działania prowadzić, jest to winne swoim obywatelkom i obywatelom" (zob. Dudek, 2014). 
cji autonomicznej i niedemokratycznej), do którego co prawda należy znaczna część społeczeństwa, ale poza nim pozostaje też spora liczba obywateli (i podatników)?

\section{Zakończenie}

Wskazane zjawiska stawiają pod znakiem zapytania możliwość funkcjonowania demokracji we współczesnej Polsce, a wolno sądzić, że mogą uniemożliwić realizowanie demokracji w dotychczasowym jej kształcie. Hipotetycznie można bowiem założyć, że odpowiedź na wszystkie postawione pytania brzmi „nie”. Po pierwsze, w zasadzie niemożliwe są zmiany, które prowadziłyby do usunięcia wskazanych przeszkód w kształtowaniu autonomicznej opinii publicznej, podatności znacznej części społeczeństwa na przyjmowanie przekazów mających charakter jedynie manipulacji, wielokrotnie posługujących się fałszem. Po drugie, z punktu widzenia demokracji największym problemem jest powierzanie władzy przez wyborców ugrupowaniom de facto likwidującym mechanizmy demokratyczne, co jest efektem nie tylko zabiegów populistycznych ze strony rządzących. Po trzecie, podłożem tego wyboru są bowiem także pewne postawy i przekonania o charakterze niesprzyjającym demokracji bądź wręcz antydemokratyczne, umiejętnie wykorzystywane przez rządzących. Po czwarte, trudno oczekiwać, że większość wyborców zainteresuje się polityką, będzie bardziej aktywna i będzie dążyć do kontroli i wpływu na partie polityczne (z wyjątkiem sytuacji kryzysu i pogorszenia warunków życia, która w Polsce mobilizuje do działania). Po piąte, wytworzone głębokie podziały polityczne, często skutkujące agresją (w tym werbalną), będą bardzo trudne do przezwyciężenia, zwłaszcza że często dotyczą kwestii symbolicznych. Wreszcie po szóste, wszystko wskazuje na to, że niezależnie od tego, jakie siły polityczne będą u władzy, pozycja i wpływy politycznie Kościoła nie zmienią się, co wynika z posiadanego przez tę instytucję potencjału mobilizacji znacznej części elektoratu.

\section{Bibliografia}

Antoszewski, A. (2019). Demokracja nieliberalna jako populistyczny wariant demokracji większościowej. W: J. Dzwończyk (red.), Polityka i gospodarka. Teoria i praktyka. Kraków: Wydawnictwo Uniwersytetu Ekonomicznego. 
Czapiński, J. (2015). Stan społeczeństwa obywatelskiego. W: J. Czapiński, T. Panek (red.), Diagnoza społeczna 2015. Warunki i jakość życia Polaków. Raport. Warszawa: Rada Monitoringu Społecznego.

Dahl, R., Stinebrickner, B. (2007). Współczesna analiza polityczna. Przeł. P.M. Kazimierczak. Warszawa: Wydawnictwo Naukowe „Scholar”.

Diamond, L. (2005). Trzy paradoksy demokracji. W: Przyszłość demokracji. Wybór tekstów. Wybór i wstęp P. Śpiewak. Przeł. P. Rymarczyk. Warszawa: Fundacja Aletheia.

Dudek, A. (2014). Polska Republika Chrześcijańska. Jak biskupi robia państwo wyznaniowe. Pobrano z: https://natemat.pl/120821,polska-republika-chrzescijanska (data dostępu: 10.10.2018).

Jarosław Kaczyński: Poza Kościołem jest tylko nihilizm. Ten nihilizm odrzucamy! Pobrano z: https://niezalezna.pl/287065-jaroslaw-kaczynski-poza-kosciolem-jesttylko-nihilizm-ten-nihilizm-odrzucamy (data dostępu: 29.12.2019).

Kaczyński: nie byłoby zwycięstwa bez o. Tadeusza Rydzyka i Rodziny Radia Maryja. Pobrano z: https://wiadomosci.wp.pl/ (data dostępu: 9.11.2018).

Karwat, M. (2016): Pseudodemokratyczne wzorce polityki. W: Antynomie i paradoksy współczesnej demokracji. Red. M. Tobiasz. Warszawa: Dom Wydawniczy Elipsa.

Linz, J. J. (2005): Kilka myśli o zwycięstwie i przyszłości demokracji. W: Przyszłość demokracji. Wybór tekstów. Wybór i wstęp P. Śpiewak. Przeł. P. Rymarczyk. Warszawa: Fundacja Aletheia.

Linz, J. J. (1998): Kryzys, załamanie i powrót do równowagi. W: Władza i społeczeństwo 2. Wybór i oprac. J. Szczupaczyński. Warszawa: Wydawnictwo Naukowe „Scholar”.

Malewska-Szałygin, A. red. (2005). Rozmowy z góralami o polityce. Warszawa: Wydawnictwo Trio.

Mowa nienawiści. Czy naprawde mamy z nia problem? Pobrano z: https://dorzeczy.pl/obserwator-mediow/90927/Mowa-nienawisci-Czy-naprawde-mamy-z-niaproblem.html (data dostępu: 29.12.2019).

Nowak, J.: Jak boty i sztuczna inteligencja niszcza demokrację 2017. Pobrano z: https://www.forbes.pl/opinie/walka-z-fake-news-jak-boty-niszcza-demokracje/ hskhy8h (data dostępu: 31.05.2019).

O polityce, która nie buduje wspólnoty, Komunikat CBOS nr 160/2017. Pobrano z:https://www.cbos.pl/SPISKOM.POL/2017/K_160_17.PDF (data dostępu: 29.12.2019).

Ocena rzadów PiS po ponad trzech latach sprawowania władzy, Komunikat CBOS nr 18/2019. Pobrano z: https://www.cbos.pl/SPISKOM.POL/2019/K_018_19.PDF (data dostępu: 29.12.2019).

Odbiór kampanii wyborczej $i$ aktywność polityczna $w$ internecie przed wyborami do Parlamentu Europejskiego. Komunikat CBOS nr 86/2019. Pobrano z: https:// www.cbos.pl/SPISKOM.POL/2019/K_086_19.PDF (data dostępu: 29.12.2019).

Pielgrzymka Rodziny Radia Maryja $201 \overline{8}$ i premier Mateusz Morawiecki na Jasnej Górze. Pobrano z: https://dziennikzachodni.pl/ (data dostępu: 5 listopada 2018). 
Płociński, M. (2019). Badania: większa nienawiść po stronie zwolenników opozycji niż PiS. Pobrano z: https://www.rp.pl/Spoleczenstwo/190129838-Badania-Wieksza-nienawisc-po-stronie-zwolennikow-opozycji-niz-PiS.html (data dostępu: 29.12.2019).

Polacy coraz bardziej podzieleni w opiniach politycznych (sondaż). Pobrano z: https://wiadomosci.dziennik.pl/polityka/artykuly/610759, polacy-podzial-opiniapolityczna-sondaz.html (data dostępu: 29.12.2019).

Psychologiczne charakterystyki elektoratów, Komunikat CBOS nr 102/2019. Pobrano z: https://www.cbos.pl/SPISKOM.POL/2019/K_102_19.PDF (data dostępu: 29.12.2019).

Raport: polski internet to pole bitwy politycznych botów 2017. Pobrano z: http:// naukawpolsce.pap.pl/aktualnosci/news\%2C $414727 \% 2$ Craport-polski-internet-topole-bitwy-politycznych-botow.html (data dostępu: 31.05.2019).

Sartori, G. (1998). Teoria demokracji. Przeł. P. Amsterdamski, D. Grinberg. Warszawa: Wydawnictwo Naukowe PWN.

Schmitter, Ph. (2005). Demokracja - zagrożenia i problemy. W: Przyszłość demokracji. Wybór tekstów. Wybór i wstęp P. Śpiewak. Przeł. P. Rymarczyk. Warszawa: Fundacja Aletheia.

Schumpeter, J. (2009): Kapitalizm, socjalizm, demokracja. Przeł. M. Rusiński. Warszawa Wydawnictwo Naukowe PWN.

Skarżyńska, K. (2012). Dla kogo Polska jest sprawiedliwie urządzonym, a dla kogo najlepszym krajem do życia? Studia Ekonomiczne $n r 4$ (LXXV) s. 537-538. Pobrano z: www.inepan.waw.pl (data dostępu: 29.12.2019).

Stosunek Polaków do związów homoseksualnych, Komunikat CBOS nr 90/2019. Pobrano z: https://www.cbos.pl/SPISKOM.POL/2019/K_090_19.PDF (data dostępu: 29.12.2019).

Sztompka, P. (2002). Socjologia. Analiza społeczeństwa. Kraków: Znak.

Werdykt wyborczy może odwrócić rzekę. Z prof. Andrzejem Zollem rozmawia Maciej Stasiński. Gazeta Wyborcza 24-25 lutego 2018.

Wiatr, J. (2019). Nowy autorytaryzm. Kryzys czy kres liberalnej demokracji. W: Dzwończyk J. (red.), Polityka i gospodarka. Teoria i praktyka. Kraków: Wydawnictwo Uniwersytetu Ekonomicznego.

Winiewski, M.i in. [Hansen K., Bilewicz, Soral W., Świderska A., Bulska D.] (2017): Mowa nienawiści, mowa pogardy. Pobrano z: http://www.batory.org.pl/upload/ files/pdf/MOWA_NIENAWISCI_MOWA_POGARDY_INTERNET. pdf (data dostępu: 29.12.2019).

Wybory samorzadowe a poczucie podmiotowości obywatelskiej. Komunikat CBOS nr 120/2018. Pobrano z: https://www.cbos.pl/SPISKOM.POL/2018/K_120_18. PDF (data dostępu: 29.12.2019).

Zasady demokracji i ich realizacja w Polsce, Komunikat CBOS nr 107/2017. Pobrano z: https://www.cbos.pl/SPISKOM.POL/2017/K_107_17.PDF (data dostępu: 29.12.2019).

Żyromski, M. (2007). Teorie elit a systemy polityczne. Poznań: Wydawnictwo Naukowe Uniwersytetu im. Adama Mickiewicza. 